\title{
PERBEDAAN TINGKAT PERKEMBANGAN ANAK USIA 3-4 TAHUN YANG TIDAK MENGIKUTI AKTIFITAS BERMAIN DAN YANG MENGIKUTI AKTIFITAS BERMAIN PAUD DI DESA JATINOM KECAMATAN KANIGORO KABUPATEN BLITAR (Differences in the Level of Development of Children Aged 3-4 Years Who Do Not Follow Play Activities and The Children Who Following Play Activities in PAUD the Village District of Kanigoro Jatinom Blitar)
}

\author{
Rizkianna Nur Wirian, Ika Agustina \\ STIKes Patria Husada Blitar \\ e-mail: ikapatria45@gmail.com
}

\begin{abstract}
Children in early childhood requires a variety of services and assistance adults, from physical to spiritual needs. The purpose of this study was to determine differences in the level of development of children aged 3-4 years who do not follow play activities and the children who following play activities in PAUD the Village District of Kanigoro Jatinom Blitar. Method: This type of research is comparative study with a cross sectional study design. Samples were taken using a sampling technique with a purposive sampling. The collection of data by using KPSP, the statistical test using the Mann Whitney test with SPSS with significance level $\alpha=0.05$. Result: The result of the research showed that the development of children aged 3-4 years who following activities almost entirely 17 (89\%) age-appropriate development. While that does not follow the activity of 8 PAUD almost half $(42 \%)$ doubted its development. Statistical test results obtained pvalue $=0.029$. In which the service is directed to facilitate growth as a proper foundation for the growth and development of the whole person, so that the child can grow and develop optimally fit values, norms, and expectations of society.
\end{abstract}

Keywords: development, play activity, children aged 3-4 years

Abstrak: Anak-anak di usia dini memerlukan berbagai layanan dan orang dewasa bantuan, dari fisik kebutuhan rohani. Tujuan dari penelitian ini adalah untuk mengetahui perbedaan tingkat perkembangan anak usia 3-4 tahun yang tidak mengikuti aktifitas bermain dan yang mengikuti aktifitas bermain PAUD di Desa Kanigoro dari Jatinom Blitar. Metode: Jenis penelitian adalah studi banding dengan desain studi cross sectional. Sampel diambil dengan menggunakan teknik pengambilan sampel dengan purposive sampling. Pengumpulan data dengan menggunakan KPSP, uji statistik menggunakan uji Mann Whitney dengan SPSS dengan tingkat signifikansi $\alpha=0,05$. Hasil: Hasil penelitian menunjukkan bahwa perkembangan anak usia 3-4 tahun yang mengikuti kegiatan hampir seluruhnya 17 (89\%) yang sesuai dengan usia perkembangan. Sementara yang tidak mengikuti aktivitas PAUD 8 hampir setengah $(42 \%)$ meragukan perkembangannya. Hasil uji statistik diperoleh nilai $p=0.029$. Di mana layanan ini diarahkan untuk memfasilitasi pertumbuhan sebagai dasar yang tepat bagi pertumbuhan dan perkembangan manusia seutuhnya, sehingga anak dapat tumbuh dan berkembang secara optimal nilai fit, norma, dan harapan masyarakat.

Kata Kunci: perkembangan, aktivitas bermain, anak usia 3-4 tahun

Perkembangan merupakan bertambahnya kemampuan (skill) dalam struktur dan fungsi tubuh yang lebih kompleks dalam pola yang teratur sebagai hasil dari proses pematangan. Di sini menyangkut adanya 
proses diferensi sel-sel tubuh, jaringan tubuh, organ dan sistem organ yang berkembang sedemikian rupa sehingga masing-masing dapat memenuhi fungsinya. Termasuk perkembangan emosi, intelektual dan tingkah laku sebagai hasil interaksi dengan lingkungan. Dalam hal ini aspek perkembangan menyangkut motorik halus, motorik kasar, bahasa maupun sosial.

Anak Usia Dini (AUD) merupakan kelompok usia yang berada dalam proses perkembangan unik, karena proses perkembangannya (tumbuh dan kembang) terjadi bersama dengan golden age (masa peka). Golden age merupakan waktu paling tepat untuk memberikan bekal yang kuat kepada anak. Pada masa peka, kecepatan perkembangan otak anak selama hidupnya. Artinya, golden age merupakan masa yang sangat tepat untuk menggali segala potensi kecerdasan anak sebanyak-banyaknya.

Anak-anak pada masa usia dini memerlukan berbagai layanan dan bantuan orang dewasa, dari kebutuhan jasmani sampai rohani. Di mana bentuk layanan tersebut diarahkan untuk memfasilitasi pertumbuhan sebagai peletakan dasar yang tepat bagi pertumbuhan dan perkembangan manusia seutuhnya, sehingga anak dapat tumbuh kembang secara optimal sesuai nilai, norma, serta harapan masyarakat. Dalam upaya mengoptimalkan segala kemampuan yang dimiliki anak usia dini yang berdasarkan prinsip PAUD, seharusnya setiap pendidikan anak usia dini (PAUD) memahami setiap tahapan pertumbuhan dan perkembangan karena segenap upaya yang dilakukannya harus berdasarkan pada tahapan tumbuh kembang anak agar mencapai hasil yang optimal.

Berdasarkan data di Departemen Kesehatan RI tahun 2010 jumlah anak usia dini (0-4 tahun) di Indonesia mencapai 23 juta, sedangkan pada tahun 2011 mencapai 23.009.874 dan pada tahun 2012 di perkirakan 23.352.721. Jumlah tersebut menunjukan jumlah anak usia dini mengalami peningkatan yang signifikan setiap tahunnya dan membutuhkan bimbingan untuk mencapai perkembangan yang optimal. Di Jawa Timur jumlah anak usia 0-6 tahun di perkirakan sekitar 4.708.453, dan sebesar 3.596.988 merupakan siswa PAUD, di dapatkan Angka Partisipasi Kasar (APK PAUD) sebesar 76,39\%. Jumlah balita di Kabupaten Blitar tahun 2008 diperkirakan sebanyak 15.393 anak, didapatkan 7,696 (50,23\%) anak usia dini belum mendapat pendidikan $5 \%$ diantaranya mengalami retardasi mental dan kemunduran kecerdasan.
Berdasarkan fenomena yang ada di PAUD Aisyiah Bustanul Atfal Desa Jatinom Kecamatan Kanigoro Kabupaten Blitar saat melakukan studi pendahuluan di bulan Juli 2014 bahwa perkembangan anak yang mengikuti aktifitas bermain di PAUD dari 8 anak, 6 (75\%) lebih bisa mandiri, disiplin, dan dari segi motorik halus, bahasa dan sosial sudah baik, sedangkan yang tidak mengkuti aktifitas bermain di PAUD dari 6 anak, 4 (66\%) belum mandiri, motorik halus, bahasa dan sosial masih belum baik dan perlu banyak bimbingan dan arahan. Hal ini karena aktifitas bermain di PAUD sudah di atur dan diawasi oleh guru, sedangkan yang tidak mengikuti aktifitas bermain di PAUD, mereka melakukan aktifitasnya sesuai dengan keinginannya tanpa di program, di atur atau tanpa perhatian khusus dari orang tua.

Bukti lain dapat dilihat dari peneliti terdahulu tentang motorik anak yang menyatakan sel otak dibentuk berdasarkan stimulasi dari luar. Hal ini dibuktikan dengan menilai perkembangan motorik anak terutama usia 3 tahun. Anak yang diberi rangsangan dini tentang perkembangan motorik kecerdasan mempunyai 10-20 point lebih tinggi dibandingkan dengan yang tidak pernah mendapatkan stimulasi.

Banyak faktor yang mempengaruhi perkembangan motorik anak. Faktor tersebut diantaranya adalah hereditas, genetis, keturunan dan lingkungan (Neny, 2005). Sumber lain menjelaskan faktor yang mempengaruhi perkembangan anak yaitu faktor dalam (keturunan) dan faktor luar (lingkungan). Dalam hal ini PAUD termasuk faktor lingkungan yakni lingkungan belajar, dimana anak mendapatkan stimulasi dari pendidik maupun temannya. Secara konsep, pendidikan usia dini ditujukan kepada anak sejak lahir sampai 6 tahun melalui pemberian rangsangan pendidikan untuk membantu pertumbuhan dan perkembangan jasmani dan rohani agar memiliki kesiapan memasuki pendidikan lebih lanjut. Anak yang mengikuti pendidikan PAUD akan mendapatkan rangsangan atau stimulasi dari pendidik secara lebih baik sehingga dapat berkembang optimal.

Untuk itu berbagai upaya dilakukan orang tua, termasuk memasukkan anaknya sejak usia dini ikut program pendidikan yang dikenal dengan PAUD. Melalui sistem ini harapannya anak dapat berkembang lebih baik karena mendapatkan stimulasi dini secara profesional dari pendidik dibandingkan jika anak tinggal di rumah. Asumsinya anak yang ikut 
PAUD mendapatkan stimulasi dini lebih baik dibandingkan anak yang tinggal di rumah. Namun demikian belum tentu perbedaan tersebut bermakna karena memang ada faktor lain yang ikut mempengaruhi perkembangan motorik halus. Jika hasilnya benar-benar menjukkan perbedaan yang bermakna, maka strategi PAUD dapat dipakai sebagai salah satu metode stimulasi dini perkembangan pada anak.

Berdasarkan latar belakang di atas maka peneliti ingin meneliti lebih lanjut tentang perbedaan tingkat perkembangan anak usia 3-4 tahun yang tidak mengikuti aktifitas bermain dan yang mengikuti aktifitas bermain PAUD di Desa Jatinom Kecamatan Kanigoro Kabupaten Blitar.

Rumusan masalah dalam penelitian ini adalah adakah perbedaan tingkat perkembangan anak usia 3-4 tahun yang tidak mengikuti aktifitas bermain dan yang mengikuti aktifitas bermain PAUD di Desa Jatinom Kecamatan Kanigoro Kabupaten Blitar. Tujuan dari penelitian ini adalah mengetahui perbedaan tingkat perkembangan anak usia 3-4 tahun yang tidak mengikuti aktifitas bermain dan yang mengikuti aktifitas bermain PAUDManfaat teoritis penelitian ini adalah Dapat menambah khasanah keilmuan terkait dengan tingkat perkembangan anak yang mengikuti yang tidak mengikuti aktifitas bermain dan yang mengikuti aktifitas bermain di PAUD. Manfaat praktis penelitian ini adalah dapat menambah dan wawasan tentang kecerdasan anak, serta dapat meningkatkan pengetahuan pemahaman dan pengalaman peneliti dalam memantapkan ilmu yang diterima selama perkuliahan agar penliti menjadi tenaga kesehatan yang aplikasinya profesional baik teori maupun praktek.

\section{METODE PENELITIAN}

Desain dalam penelitian ini adalah comparative study. Dengan pendekatan cross sectional. Subyek penelitian ini adalah anak usia 3-4 tahun sebanyak 38 anak (19 anak di PAUD Aisyiah Bustanul Atfal dan19 anak yang tidak mengikuti PAUD) yang dilaksanakan pada tanggal 21-23 Agustus tahun 2014. Subyek penelitian ini dipilih secara purposive sampling. Setelah data terkumpul, maka dilakukan analisa data dan selanjutnya dilakukan uji statistik menggunakan uji Wilcoxon.

\section{HASIL PENELITIAN}

\section{Data Umum}

Tabel 1. Karakteristik Responden Tingkat Perkembangan Anak yang Mengikuti Aktifitas Bermain di PAUD

\begin{tabular}{lll}
\hline \multicolumn{1}{c}{ Karakteristik } & F & \% \\
\hline Umuribu & & \\
<20 tahun & 1 & 0 \\
20-35 ahun & 4 & 79 \\
>35 tahun & 3 & 21 \\
Pendidikan & & \\
SMP & 0 & 0 \\
SMU & 14 & 74 \\
Pend. Tinggi & 5 & 26 \\
Pekerjaan & & \\
IRT & 5 & 26 \\
Wiraswasta & 9 & 48 \\
Peg. Swasta & 1 & 5 \\
PNS & 4 & 21 \\
Tani & 0 & 0 \\
Jumlah anak & & \\
1 & 13 & 69 \\
2 & 4 & 21 \\
3 & 1 & 5 \\
4 & 1 & 5 \\
Pengasuhan & & \\
Ibu & 2 & 89 \\
Nenek & 19 & 11 \\
Umur & & \\
36-42 bulan & 11 & 58 \\
43-48 bulan & 8 & 42 \\
Jenis kelamin & & \\
Laki-laki & 13 & 68 \\
Perempuan & 6 & 32 \\
\hline
\end{tabular}

\section{Data Khusus}

Berdasarkan tabel 3 menunjukkan bahwa hampir seluruh responden 17 (89\%) perkembangannya sesuai dengan usia.

Berdasarkan tabel 4 menunjukkan bahwa hampir setengahnya responden 8 (42\%) perkembangannya meragukan.

Berdasarkan tabel 5 menunjukkan bahwa hampir seluruh responden 17 (89\%) yang mengikuti aktifitas PAUD perkembangannya sesuai dengan usia dan sebagian besar responden yang tidak mengikuti aktifitas PAUD 11 (58\%) perkembangannya sesuai dengan usia. 
Tabel 2. Karakteristik Responden Tingkat Perkembangan Anak yang Tidak Mengikuti Aktifitas Bermain di PAUD

\begin{tabular}{|c|c|c|c|}
\hline No & Karakteristik & $\mathbf{f}$ & $\%$ \\
\hline \multirow[t]{4}{*}{1} & Umur ibu & & \\
\hline & $<20$ tahun & 1 & 5 \\
\hline & 20-35 ahun & 15 & 79 \\
\hline & $>35$ tahun & 3 & 16 \\
\hline \multirow[t]{3}{*}{2} & $\begin{array}{l}\text { Pendidikan } \\
\text { SMP }\end{array}$ & & \\
\hline & SMU & 14 & 74 \\
\hline & Pend. Tinggi & 5 & 26 \\
\hline \multirow[t]{6}{*}{3} & Pekerjaan & & \\
\hline & IRT & 10 & 53 \\
\hline & Wiraswasta & 6 & 31 \\
\hline & Peg. Swasta & 0 & 0 \\
\hline & PNS & 0 & 0 \\
\hline & Tani & 3 & 16 \\
\hline \multirow[t]{5}{*}{4} & Jumlah anak & & \\
\hline & 1 & 7 & 36 \\
\hline & 2 & 6 & 32 \\
\hline & 3 & 3 & 16 \\
\hline & 4 & 3 & 16 \\
\hline \multirow[t]{3}{*}{5} & Pengasuhan & & \\
\hline & Ibu & 15 & 79 \\
\hline & Nenek & 4 & 21 \\
\hline \multirow[t]{3}{*}{6} & Umur & & \\
\hline & $36-42$ bulan & 12 & 63 \\
\hline & 43-48 bulan & 7 & 37 \\
\hline \multirow[t]{3}{*}{7} & Jenis kelamin & & \\
\hline & Laki-laki & 9 & 48 \\
\hline & Perempuan & 10 & 52 \\
\hline
\end{tabular}

Tabel 3. Distribusi Frekuensi Perkembangan Anak Usia 3-4 Tahun yang Mengikuti Aktifitas PAUD

\begin{tabular}{clcc}
\hline No & Perkembangan & Frekuensi & \% \\
\hline 1 & Sesuai & 17 & 89 \\
2 & Meragukan & 2 & 11 \\
3 & Penyimpangan & 0 & 0 \\
\hline
\end{tabular}

Tabel 4. Distribusi Frekuensi Perkembangan Anak Usia 3-4 Tahun yang Tidak Mengikuti Aktifitas PAUD

\begin{tabular}{clcc}
\hline No & Perkembangan & Frekuensi & \% \\
\hline 1 & Sesuai & 11 & 58 \\
2 & Meragukan & 8 & 42 \\
3 & Penyimpangan & 0 & 0 \\
\hline
\end{tabular}

Tabel 5. Distribusi Frekuensi Perbedaan Perkembangan Anak Usia 3-4 Tahun yang Mengikuti Aktifitas PAUD dan Tidak Mengikuti Aktifitas PAUD

\begin{tabular}{cccccccc}
\hline \multirow{2}{*}{ No } & Aktitas PAUD & \multicolumn{6}{c}{ Perkembangan } \\
\cline { 3 - 7 } & & Sesuai & \multicolumn{1}{c}{ Meraguka } & Peyimpa ngan \\
\cline { 3 - 7 } & f & $\%$ & f & $\%$ & f & $\%$ \\
\hline 1 & Mengikuti & 17 & 89 & 2 & 11 & 0 & 0 \\
2 & $\begin{array}{c}\text { Tidak } \\
\text { mengikuti }\end{array}$ & 11 & 58 & 8 & 42 & 0 & 0
\end{tabular}

Berdasarkan hasil Uji statistic dengan menggunakan Uji Mann Whitney didapatkan pvalue = 0,029 . Karena pvalue $(0.029)<\alpha 0.05$ maka Ada perbedaan tingkat perkembangan anak usia 3-4 tahun yang tidak mengikuti aktifitas bermain dan yang mengikuti aktifitas bermain PAUD di Desa Jatinom Kecamatan Kanigoro Kabupaten Blitar.

\section{PEMBAHASAN}

Tingkat Perkembangan Anak Usia 3-4 Tahun yang Mengikuti Aktifitas PAUD di Desa Jatinom Kanigoro Blitar

Hasil penelitian menunjukkan bahwa hampir seluruh responden 17 (89\%) perkembangannya sesuai dengan usia, dan $2(11 \%)$ dengan perkembangan meragukan.

Perkembangan merupakan perubahan mental yang berlangsung secara bertahap dan dalam waktu tertentu, dari kemampuan yang sederhana menjadi kemampuan yang lebih sulit, misalnya kecerdasan, sikap, dan tingkah laku. Tumbuh kembang masing masing anak berbeda tergantung faktor bakat (genetik), lingkungan (gizi dan cara perawatan), dan konvergensi yaitu perpaduan antara bakat dan lingkungan (Susanto, 2011).

Kemampuan, ketrampilan dan pengetahuan anak dibangun berdasakan pada apa yang sebelumnya telah diperolehnya, meskipun terdapat berbagai variasi perkembangan anak sesuai kultur budaya setempat namun secara umum urutan perkembangan tersebut mengikuti pola dan urutan tertentu yang dapat diperkirakan. Dengan demikian perkembangan merupakan proses yang berkesinambungan di mana pengalaman belajar dan ketercapaiannya tugas perkembangan pada suatu periode akan mendasari proses perkembangan berikutnya. 
Pendidikan anak usia dini merupakan salah satu bentuk penyelenggaraan pendidikan yang menitik beratkan pada keletakan dasar ke beberapa arah sebagai berikut: 1) Pertumbuhan dan perkembangan fisik (koordinasi motorik halus dan kasar), 2) Kecerdasan (daya fikir, daya cipta, kecerdasan emosi dan kecerdasan spiritual), 3) Sosioemosional (sikap dan perilaku serta agama) bahasa dan komunikasi, yang disesuaikan dengan keunikan dan tahap perkembangan yang dilalui oleh anak usia dini.

Sistem lingkungan sosial yang terdiri dari 2 atau lebih sistem mikro seperti interaksi antar keluarga (interfamily interaction), interaksi antar sekolah (interschool interaction), interaksi antar kelompok teman sebaya (peer group interaction). Seorang anak yang dapat menyelesaikan tugas-tugas pekerjaan rumah yang diberikan oleh guru di sekolah, cenderung akan merasa puas, percaya diri, bangga dan mengembangkan kepribadian yang positif, dibandingkan dengan anak yang gagal dalam menyelesaikan tugas pekerjaan rumah. Sistem lingkungan sosial tidak langsung memberi pengaruh perkembangan anak. Sistem ini antara lain terdiri dari tempat kerja orang tua, jaringan sosial orang tua (parents social network). Seorang ibu yang bekerja yang hanya memperoleh kesempatan cuti dalam waktu singkat, cenderung memberi perhatian terhadap anak-anaknya secara penuh pada hari-hari libur saja.

Hasil penelitian menunjukkan bahwa anak yang mengikuti aktifitas bermain PAUD hampir seluruhnya perkembangannya sesuai dengan usia. Menurut Kartono (2004), bahwa perkembangan motorik kasar anak usia 3-4 tahun yaitu berdiri satu kaki dua detik sampai lima detik dan melompat dengan satu kaki, sedangkan motorik halus yaitu menggoyangkan ibu jari, memilih garis yang lebih panjang, mencontoh Lingkaran, mencontoh + dan menggambar orang 3 bagian. Perkembangan bahasa yaitu sudah tahu tentang nama-nama binatang, menyebutkan nama benda yang di lihat di buku, mengenal warna, bisa mengulang empat digit angka, bisa mengulang kata dengan empat suku kata dan suka mengulang kata, frasa, suku kata, bunyi. Sedangkan perkembangan sosial anak yaitu mengembangkan sikap percaya terhadap orang lain, mengembangkan pemahaman tentang tingkah laku sosial, belajar menyesuaikan perilaku dengan tuntutan lingkungan, belajar memahami pandangan orang lain dan merespon harapan atau pendapat mereka secara selektif dan memiliki pemahaman untuk mengatur diri dan memahami kriteria untuk menilai penampilan atau perilaku sendiri.

Perkembangannya anak usia 3-4 tahun sudah sesuai dengan usianya, hal ini karena usia 3-4 tahun termasuk usia kelompok bermain, yaitu kelompok masyarakat yang paling mudah untuk menerima segala permainan, dalam hal ini bergantung pada bantuan ibu maupun gurunya. Dalam pendidikan PAUD pada usia 3-4 tahun ini anak sudah di ajarkan melakukan permainan yang bervariasi untuk mencegah kebosanan, memberikan sesuatu yang baru untuk melatih dan merangsang prekembangan anak. Anakanak yang mengikuti PAUD menjadi lebih mandiri, disiplin, dan mudah diarahkan untuk menyerap ilmu pengetahuan secara optimal. Ibarat jalan masuk menuju pendidikan dasar PAUD memuluskan jalan masuk pendidikan dasar. Konsep bermain sambil belajar sambil bermain pada PAUD merupakan pondasi yang mengarahkan anak pada pengembangan kemampuan yang lebih beragam. Komponen yang diakses meliputi seluruh aspek perkembangan anak.

Di samping itu faktor pendidikan ibu juga berperan penting dalam memberikan arahan dan pola perkembangan anak, di mana pendidikan ibu dengan anak yang tidak mengikuti aktifitas PAUD sebagian besar $14(74 \%)$ berpendidikan SMU. Menurut Notoatmodjo (2007), tingkat pendidikan turut pula menentukan mudah tidaknya seseorang menyerap dan memahami pengetahuan yang mereka peroleh, pada umumnya semakin tinggi pendidikan seseorang maka akan semakin baik pula pengetahuannya. Dengan pendidikan yang sebagian besar sekolah menengah atas maka akses informasi dan pola fikir ibu dalam menerapkan pola asuh dalam mencapai perkembangan anak yang optimal akan lebih mudah tercapai.

Selain faktor pendidikan, faktor pengasuhan orang tua juga sangat membantu anak dalam mencapai pertumbuhan yang optimal, dimana anak yang mengikuti aktifitas PAUD hampir seluruhnya 17 (89\%) di asuh oleh ibu. Menurut Harlock (2007), pola asuh yang baik akan menghasilkan karekteristik anak yang mandiri, dapat mengontrol diri, mempunyai hubungan baik dengan temannya dan mempunyai minat terhadap hal-hal baru. Pola asuh yang baik membantu anak untuk dapat mengembangkan diri berdasarkan kemampuannya. Dengan di asuh oleh ibu maka seorang ibu akan mengikuti perkembangan anak setiap saat, pencapaian dan informasi hasil perkembangan anak di PAUD akan ditindak lanjuti oleh ibu di rumah, anak akan lebih ekspresif 
dan eksploratif manakala diasuh oleh ibunya, sehingga membuatnya komunikasi antara ibu dan guru PAUD akan lebih terarah, saling memberikan evaluasi hasil pencapaian perkembangan anak baik di rumah maupun di sekolah PAUD.

Sedangkan hasil penelitian sebagian kecil (11\%) perkembangan anak meragukan, hali ini karena setiap perkembangan anak antara yang satu dengan yang lainnya memang berbeda. Kalau dikaitkan dengan karakteristik responden dimana sebagian besar $11(58 \%)$ berusia 3-4 tahun artinya pada usia tersebut sebagian besar anak masih belum bisa sepenuhnya berinteraksi dengan orang lain sehingga pola perkembangan anak menjadi kurang baik apalagi anak-anak yang seringkali dimanjakan oleh orang tua. Dengan anak yang usia 3 tahun ke khawatiran orang tua sangat tinggi bila anak melakukan permainan yang mempunyai resiko jatuh dan orang tua cenderung memarahi, sehingga hal ini akan membuat anak menjadi kurang berkembang dan kurang kreatifitas.

Selain faktor usia jenis kelamin juga berkonstribusi terhadap perkembangan anak, di mana terdapat $32 \%$ anak dengan jenis kelamin perempuan. Anak perempuan cenderung lebih kurang berani dalam berinteraksi dengan orang lain, dalam permainan yang jenisnya permainan motorik, sehingga kecenderungan akan lebih lambat dibanding dengan anak laki-laki. Anak laki-laki cenderung lebih agresif dan ekspresif dalam permainan yang melibatkan motorik.

\section{Tingkat Perkembangan Anak Usia 3-4 Tahun Yang Tidak Mengikuti Aktifitas PAUD di Desa Jatinom Kanigoro Blitar}

Hasil penelitian menunjukkan bahwa hampir setengahnya responden 8 (42\%) perkembangannya meragukan.

Perkembangan merupakan perubahan yang dialami individu atau organisme menuju tingkat kedewasaannya atau kematangannya (maturation) yang berlangsung secara sistematis, progresif dan berkesinambungan, baik menyangkut fisik (jasmaniah) maupun psikis (rohaniah) (Yusuf, 2011).

Kemampuan, ketrampilan dan pengetahuan anak di bangun berdasakan pada apa yang sebelumnya telah diperolehnya, meskipun terdapat berbagai variasi perkembangan anak sesuai kultur budaya setempat namun secara umum urutan perkembangan tersebut mengikuti pola dan urutan tertentu yang dapat diperkirakan. Dengan demikian perkembang- an merupakan proses yang berkesinambungan di mana pengalaman belajar dan ketercapaiannya tugas perkembangan pada suatu periode akan mendasari proses perkembangan berikutnya.

Perkembangan seseorang amat ditentukan oleh faktor lingkungannya. Lingkungan memiliki peran besar bagi perubahan yang positif maupun negatif pada individu. Hal ini tergantung bagaimana karateristik lingkungan itu sendiri. Lingkungan yang baik tentu membawa pengaruh positif bagi individu, sebaliknya lingkungan yang kurang baik, rusak dan buruk cenderung akan memperburuk perkembangan individu. Dan faktor lingkungan tersebut bersifat stratifikasi berlapis-lapis dari yang terdekat sampai terjauh, yaitu sebagai suatu sistem mikro (microsystem), sistem meso (mesosystem), sistem ekso (exosystem), sistem makro (macrosystem) dan sistem krono (kronosystem).

Hasil penelitian menunjukkan bahwa anak yang tidak mengikuti aktifitas bermain PAUD sebagian besar perkembangannya meragukan. Menurut Kartono (2004), bahwa perkembangan motorik kasar anak usia 3-4 tahun yaitu berdiri satu kaki dua detik sampai lima detik dan melompat dengan satu kaki, sedangkan motorik halus yaitu menggoyangkan ibu jari, memilih garis yang lebih panjang, mencontoh lingkaran, mencontoh + dan menggambar orang 3 bagian. Perkembangan bahasa yaitu sudah tahu tentang nama-nama binatang, menyebutkan nama benda yang dilihat di buku, mengenal warna, bisa mengulang empat digit angka, bisa mengulang kata dengan empat suku kata dan suka mengulang kata, frasa, suku kata, bunyi. Sedangkan perkembangan sosial anak yaitu mengembangkan sikap percaya terhadap orang lain, mengembangkan pemahaman tentang tingkah laku sosial, belajar menyesuaikan perilaku dengan tuntutan lingkungan, belajar memahami pandangan orang lain dan merespon harapan atau pendapat mereka secara selektif dan memiliki pemahaman untuk mengatur diri dan memahami kriteria untuk menilai penampilan atau perilaku sendiri.

Perkembangan anak yang tidak mengikuti aktifitas bermain PAUD sebagian besar perkembangannya meragukan, hal ini karena anak yang tidak mengikuti aktifitas bermain PAUD kurang ada stimulasi perkembangan yang memberikan arah dan bimbingan untuk mencapai perkembangan yang optimal. Kecenderungan aktifitas yang dikerjakan anak berdasarkan dunianya sendiri tanpa ada program yang terstruktur yang mampu menjembatani 
anak untuk bermain dan bereksplorasi, akibatnya perkembangan yang berjalan jauh dari apa yang diharapkan untuk menjadi anak yang benar-benar berkualitas.

Di samping itu faktor pendidikan ibu juga berperan penting dalam memberikan arahan dan pola perkembangan anak, dimana pendidikan ibu dengan anak yang tidak mengikuti aktifitas PAUD hampir setengahnya $26 \%$ berpendidikan SMP. Menurut Notoatmodjo (2007), tingkat pendidikan turut pula menentukan mudah tidaknya seseorang menyerap dan memahami pengetahuan yang mereka peroleh, pada umumnya semakin tinggi pendidikan seseorang maka akan semakin baik pula pengetahuannya. Dengan pendidikan SMP maka kemampuan ibu untuk menganalisis informasi dan menerapkan pola asuh dalam mencapai perkembangan anak yang optimal akan sulit tercapai, kemampuan mengenal dan evaluasi terhadap perkembangan anak akan sulit terwujud sehingga berakibat pada berbagai macam hambatan pada perkembangan anak.

Selain faktor pendidikan, faktor pengasuhan orang tua juga sangat membantu anak dalam mencapai pertumbuhan yang optimal, dimana anak yang mengikuti aktifitas PAUD hampir seluruhnya 79\% di asuh oleh ibu. Menurut Harlock (2007), Pola asuh yang baik akan menghasilkan karekteristik anak yang mandiri, dapat mengontrol diri, mempunyai hubungan baik dengan temannya dan mempunyai minat terhadap hal-hal baru. Pola asuh yang baik membantu anak untuk dapat mengembangkan diri berdasarkan kemampuannya. Walaupun di asuh oleh ibu tetapi karakteristik ibu yang kurang mendukung maka akan sulit mencapai perkembangan yang optimal, karena pada hakikatnya perkembangan anak sangat di pengaruhi oleh factor lingkungan, semakin berkualitas lingkungan yang mendukungnya, maka akan di ikuti oleh perkembangan anak yang lebih baik. Semua factor tersebut memberikan konstribusi penting dalam perkembangan anak saat ini.

\section{Perbedaan Tingkat Perkembangan Anak Usia 3-4 Tahun yang Tidak Mengikuti Aktifitas dan yang Mengikuti Aktifitas PAUD di Desa Jatinom Kanigoro Blitar}

Hasil penelitian menunjukkan bahwa hampir seluruh responden 17 (89\%) yang mengikuti aktifitas PAUD perkembangannya sesuai dengan usia dan hampir setengahnya responden yang tidak mengikuti aktifitas PAUD 8 (42\%) perkembangannya meragukan. Berdasarkan hasil Uji statistic dengan menggunakan Uji Mann Whitney didapatkan pvalue $=0,029$. Karena pvalue $(0.029)<\alpha 0.05$ maka Ada perbedaan tingkat perkembangan anak usia 3-4 tahun yang tidak mengikuti aktifitas bermain dan yang mengikuti aktifitas bermain PAUD di Desa Jatinom Kecamatan Kanigoro Kabupaten Blitar tahun 2014.

Pendidikan usia dini merupakan upaya pembinaan yang ditujukan bagi anak lahir sampai usia 6 tahun yang dilakukan dengan memberi rangsangan pendidikan untuk membantu pertumbuhan dan perkembangan jasmani dan rohani agar anak memiliki kesiapan memasuki pendidikan lebih lanjut.

Perkembangan merupakan perubahan mental yang berlangsung secara bertahap dan dalam waktu tertentu, dari kemampuan yang sederhana menjadi kemampuan yang lebih sulit, misalnya kecerdasan, sikap, dan tingkah laku. Tumbuh kembang masing masing anak berbeda tergantung faktor bakat (genetic), lingkungan (gizi dan cara perawatan), dan konvergensi (perpaduan antara bakat dan lingkungan) (Susanto, 2011).

Kemampuan, ketrampilan dan pengetahuan anak dibangun berdasakan pada apa yang sebelumnya telah diperolehnya, meskipun terdapat berbagai variasi perkembangan anak sesuai kultur budaya setempat namun secara umum urutan perkembangan tersebut mengikuti pola dan urutan tertentu yang dapat diperkirakan. Dengan demikian perkembangan merupakan proses yang berkesinambungan dimana pengalaman belajar dan ketercapaiannya tugas perkembangan pada suatu periode akan mendasari proses perkembangan berikutnya.

Hasil penelitian menunjukkan bahwa ada perbedaan tingkat perkembangan anak usia 3-4 tahun yang tidak mengikuti aktifitas bermain dan yang mengikuti aktifitas bermain PAUD di Desa Jatinom Kecamatan Kanigoro Kabupaten Blitar tahun 2014. Hal ini di sebabkan karena anak yang mengikuti aktifitas bermain PAUD dititik beratkan pada keletakan dasar ke beberapa arah sebagai berikut: 1) Pertumbuhan dan perkembangan fisik (koordinasi motorik halus dan kasar), 2) Kecerdasan (daya fikir, daya cipta, kecerdasan emosi dan kecerdasan spiritual), 3) Sosioemosional (sikap dan perilaku serta agama) bahasa dan komunikasi, yang disesuaikan dengan keunikan dan tahap perkembangan yang dilalui oleh anak usia dini. Hal inilah yang membedakan keterarahan anak yang mengikuti dan tidak mengikuti aktifitas PAUD, tentunya hasil perkembangan 
yang di capai anak akan berbeda pula. Anak yang tidak mengikuti aktifitas bermain PAUD kurang ada stimulasi perkembangan yang memberikan arah dan bimbingan untuk mencapai perkembangan yang optimal. Kecenderungan aktifitas yang dikerjakan anak berdasarkan dunianya sendiri tanpa ada program yang terstruktur yang mampu menjembatani anak untuk bermain dan bereksplorasi, akibatnya perkembangan yang berjalan jauh dari apa yang diharapkan untuk menjadi anak yang benar-benar berkualitas.

\section{SIMPULAN dan SARAN}

\section{Simpulan}

Hasil penelitian menunjukkan bahwa perkembangan anak usia 3-4 tahun yang mengikuti kegiatan hampir seluruhnya 17 (89\%) yang sesuai dengan usia perkembangan. Sementara yang tidak mengikuti aktivitas PAUD 8 hampir setengah (42\%) meragukan perkembangannya. Hasil uji statistik diperoleh nilai $\mathrm{p}=0.029$.

\section{Saran}

Bagi profesi kesehatan khususnya kebidanan hendaknya lebih giat dan aktif dalam memberikan penyuluhan, informasi, dan edukasi tentang deteksi perkembangan anak di lingkungan PAUD secara berkala yang sesuai kebutuhan.

Diharapkan pendidikan PAUD terus mengembangkan variasi permainan dan pembelajaran untuk menstimulasi perkembangan anak sedini mungkin agar anak bisa berkembang secara optimal sehingga bisa menjadi anak yang kerkualitas.

\section{DAFTAR RUJUKAN}

Hurlock. 2007. Psikologi Perkembangan,Suatu Pendekatan Sepanjang Rentang Kehidupan. Jakarta: Erlangga

Kartono, K. 2004. Psikologi Anak. Bandung: Mondar Maju.

Neny. 2005. Perkembangan Motorik Anak Taman Kanak-Kanak. Jakarta: Puspa Swara.

Notoatmodjo, S. 2005. Metodologi Penelitian. Jakarta: Rineka Cipta.

Susanto, A. 2011. Perkembangan Anak Usia Dini. Jakarta: Kencana Prenada Media Groub.

Yusuf. 2011. Psikologi Perkembangan Anak dan Remaja. Bandung: PT Remaja Rosda Karya Offset. 